\title{
ECONOMIC ASPECTS OF SHEEP FARMING ON THE FAMILY FARM MODELS IN THE HILLY-MOUNTAIN REGIONS OF SERBIA
}

\author{
Nikola Popović ${ }^{1}$ \\ *Corresponding authorE-mail: nikpop@agrif.bg.ac.rs
}

A R T I C L E I N F O
Original Article
Received: 26 September 2018
Accepted: 02 November 2018
doi:10.5937/ekoPolj1804395P
UDC 338.434:636.32/.38(497.11)(23)

Keywords:

hilly-mountain regions, family farm models, sheep production, Direct costing calculation, gross margin

JEL: Q10, D10/

\section{A B S T R A C T}

The hilly-mountain villages are important factor in food production and rural development of Serbia. The sheep production is in the fourth place of importance among branches of livestock production in Serbia, behind the cattle, pig and poultry productions. The aim of the paper is to analyze economic indicators of the sheep farming on family farms in Serbian hilly-mountain regions on the basis of 4 models which differ in intensity of crop and sheep production and to consider possibilities for improvement. The analysis has been done on the basis of data collected on 30 family farms. The economic indicators have been calculated on the basis of Direct costing calculation method and gross margins. The results have shown that production of lamb meat and sheep cheese represent the main source of the family farms' income in the hilly-mountain regions. The Model D with intensive crop and sheep production obtained the best economic results.

(C) 2018 EA. All rights reserved.

\section{Introduction}

Successful occupation with sheep production place farmers in front of certain financial and organizational requirements. Obtaining of successful economic results contributes to increased income and standard of living of family farms, and therefore their sustainability in the hilly-mountainous areas.

Sheep breeding is an important branch of agriculture, because it can be the best use of natural resources, especially in the hilly-mountain regions of Republic of Serbia. Thanks to the biological characteristics, sheep is adapted for growing in different climatic conditions. Sheep are primarily adapted for growing on pastures, where other types of domestic animals cannot be bred. Sheep breeding offers the possibility of obtaining three useful products: meat, milk and wool. Meat of sheep and lambs by the content of dry matter exceeds the pork and beef meat, and sheep milk has a higher percentage of fat, protein and dry matter than cow's milk. In Serbia the focus is on the production of lamb meat.

1 Nikola Popović, M.Sc., Teaching Assistant, University of Belgrade, Faculty of Agriculture, Nemanjina 6, 11080 Zemun, Serbia, Phone: +381 11 4413215, e-mail: nikpop@agrif.bg.ac.rs http://ea.bg.ac.rs 
Effective fattening of lambs, and thus the production of meat is conditioned by a lot of factors, of which particularly should be noted the characteristics of race, age, sex, the individual properties of sheep, the effect of castration, type of feed and the composition of meals. Profitability of lamb fattening depends on the value of the animals that enter the breeding, value of feed, feed costs, depreciation of buildings and equipment, production risk and other expenses (Pavličević et al., 2000).

Australian industry of lamb and sheep meat drawn up a strategic plan within which gave the top priority to research methods and principles for the delivery of lamb meat and carcasses that should be of adequate size with more muscle and less fat (Pethick DW et al., 2006).

Conditions for growing sheep are especially preferred in the hilly-mountain areas of Serbia, where there are about $1,700,000$ ha natural pastures, which is a prerequisite for keeping a large number of sheep. That is why it is grown in this region more than $70 \%$ of total sheep heads in Serbia. However, breeding of sheep in these regions is usually in the form of extensive or semi-intensive manufacture (Mekić et al., 2006).

Sheep are expressive herbivores, which in the case of sole nutrition voluminous (bulky) feeding system, even if it is mediocre one, provide a very valuable products for human consumption (meat and milk), and in addition to that wool, leather and manure that is very convenient for plant production. Sheep are mostly grazing animals and they better use the grazing than the cattle (Pavličević, 2001).

Sheep production is mainly concentrated in the hilly-mountainous areas where there are more opportunities for grazing and those areas of Serbia have great potential for development of sheep production. Agricultural 2012 Census shows that sheep production is largely concentrated in the Region of Šmadija and Western Serbia. In this Region there have been grown on private family farms almost $60 \%$ of all sheep grown in Serbia.

However, the big problem in sheep production in the hilly-mountainous areas is provision the high-quality forage, especially during the winter season, because the vegetation period is short.

Autochthonous production of milk and cheese has been preserved in households of hillymountainous areas. In those areas the basic branch of agriculture is livestock and within it the production of milk and meat occupies the most important place. One of the most famous indigenous dairy products characteristic for the whole area of Serbia is the sheep cheese. It belongs to the group of white cheeses in brine and it has been produced as a traditional cheese from sheep or mixed sheep and cow's milk (Jovanović et al., 2004).

Sheep production in Republic of Serbia is characterized by low productivity, poor quality of products, extensive way of growing and permanently decline in the number of sheep. Although our country has favorable natural conditions for development of sheep production, Serbia has been still deficient in the production of meat, milk and dairy products (Sredojević and Popović, 2014). 
The most common sheep breed in Serbia is Pramenka. This is a sheep with triple production capacity, because it is grown for the production of milk, meat and wool. There are several breeds of Pramenka: Sjenica or Pester sheep, Svrljig sheep, Pirot sheep, Sarplanina sheep and some others breeds which are highly adapted to the reduced circumstances and conditions under which they have been grown.

Pramenka is primitive sheep and it is a result of the poor nutrition and care conditions, to which it has been well adapted during long period of time. It is very resistant and durable. Pramenka was once widespread throughout Europe (France, Germany, England, Romania and Hungary). By intensification of agricultural production Pramenka was replaced by better sheep breeds, but this breed has been maintained to a large percentage in Southern Europe, especially on the Balkans (Krajinović, 2006).

\section{Materials and methods}

For the analysis of economic indicators in sheep production, there have been used different organizational and economic models. Modeling is a form of simulation in which it is possible to see all organization, economic and investment aspects of sheep production on family farms. Through modeling it could be simply solved many problems that are typical for this type of agricultural production. Creating of model is necessary when it is impossible to show the real state with all validity and relations. These observations could be applied to all economic entities, including the family farms.

The family farms models represent a group of economic, production-business and organization models (Tomic, 1994). During the creation of the family farm models directed to the sheep production, an attention has been focused on the following criteria: the intensity of animal feed production, intensity of sheep production, type of meals and farm size (Krstić et al., 1995). Beside the mentioned criteria, in creation of the models it is necessary to pay attention to the size of land area as well as the type of the sheep production (Bulatović, 1996).

The main objective of this research was to determine the economic indicators (production value and costs) achieved in sheep production. In addition the focus was on possibility of increasing the total production value of the observed family farms, because in addition to the production of lambs and lamb meat on the family farms, it is also present the milk processing into the high quality sheep cheese.

For analysis of obtained data, it was used the analytical calculations based of variable costs so-called Direct cost calculation. In addition to that, there have been used the following methodological tools: description, analysis, synthesis, comparison and methods of descriptive statistics. Results are presented in the form of tables.

A questionnaire was created for research purposes at the family farms. For every analyzed family farm there were made particular versions for lower and higher levels of intensity, depending on: forage production, the sheep production intensity and type of meals. 


\section{Results and discussions}

As the family farms have an important place in the production and resources in Serbian agriculture, it requires to be determined the economic results of those farms. Economic indicators of production can be monitored if the farm regularly recorded production costs and results (Popović, 2012). Unfortunately, most farmers do not keep nor present the operating costs and results, even the simplest indicators.

The theoretical basis for the preparation of analytical calculation and determination of the production costs has been obtained in the direct costing method developed in USA, according to which the calculation of individual production line costs includes only those costs that change in proportion to the changes in production volume - i.e. variable costs (Andrić, 1998).

In these calculations, in addition to the variable costs, it is calculated the production value, and the corresponding operating result which comes from the difference between the production value and the variable costs. This result is marked in literature by different names such as contribution margin, gross margin, the margin of coverage, net income (Gogić, 2009).

The gross margin shows the result which after covering variable costs remains to cover fixed costs and to achieve the positive financial results (Vasiljević, Subić, 2010).

\section{Formulation of the sheep production models with 100 sheep per model}

The starting assumptions in the model are that the family farm is located in the hillymountainous region, at an altitude of more than 1000 meters, and that it is oriented exclusively on sheep production. Sheep production in the family farm model means the production of meat (lambs and culled sheep), sheep milk and cheese as well as wool. The size of the farm is 100 sheep. The farm in the model is also dealing with crop production, which is fully utilized to provide the necessary animal feed for a sheep. The most field crops on the farm are barley and oat as the feed grains and hay is supplied from the natural pastures or cultivated fields and it serves as forages. Concentrates and other supplements are purchased on the market. The labor activities on the family farm have been carried out by the family farm members, and those are primarily operations involving in sheep milking and processing of milk into sheep cheese, then herding of sheep in the pastures, mowing meadows and hay making, cleaning stables for sheep, cultivation and alike. The assumption is the family farm has its own equipment, machinery for farming and sheep production and ground objects for cattle.

Assumption in the model is that the family farm has 20 hectares of land from which 15 ha is arable land and meadows and remaining 5 ha are pastures. Sheep are pregnant around 150 days, the lambs suckling 3 months, but after a month it has been added the hay. Length of the grazing period is from April to November or December, until the snow thickness exceeds $10 \mathrm{~cm}$. The summer meal consists of pasture grass, while in winter meal there have been given the hay and grains (barley and oat). The farm uses public meadows and pastures. 
Based on the intensity of crop and sheep production, it is possible to form 4 family farm models (Table 1).

Table 1. Models of family farms according to the level of crop and sheep production intensity

\begin{tabular}{|c|c|c|c|c|}
\hline \multirow{2}{*}{$\begin{array}{c}\text { Serial } \\
\text { number }\end{array}$} & \multirow{2}{*}{ Symbol } & \multicolumn{2}{|c|}{ Level of production intensity } & \multirow{2}{*}{$\begin{array}{c}\text { Number of } \\
\text { sheep }\end{array}$} \\
\cline { 3 - 4 } & & Crop production & Sheep production & 100 \\
\hline 01. & $\mathrm{~A}$ & extensive & extensive & 100 \\
\hline 02. & $\mathrm{~B}$ & intensive & extensive & 100 \\
\hline 03. & $\mathrm{C}$ & extensive & intensive & 100 \\
\hline 04. & $\mathrm{D}$ & intensive & intensive & \\
\hline
\end{tabular}

Source: Author's research

\section{Crop production}

The research of economic parameters of sheep production is based on the determination of total production value and production costs. Lambs that have low body weight are not suitable for sale, but they must weigh 35 to $40 \mathrm{~kg}$ in 3-4 months. Only then, the animal which reach this weight, may be sold as breeding material or to the slaughterhouse.

Table 2. Costs of production per 1 ha of oat - extensive crop production

\begin{tabular}{|c|c|c|c|c|}
\hline Indicators & $\begin{array}{c}\text { Unit of } \\
\text { measure }\end{array}$ & Volume & Price $(€)$ & $\operatorname{Sum}(€)$ \\
\hline \multicolumn{5}{|l|}{ 1. Production value } \\
\hline - grain & $\mathrm{kg}$ & 2,100 & \multicolumn{2}{|c|}{ internal realization } \\
\hline - straw & $\mathrm{kg}$ & 1,700 & \multicolumn{2}{|c|}{ internal realization } \\
\hline \multicolumn{5}{|l|}{ 2. Direct variable costs } \\
\hline - fertilizers & $\mathrm{kg}$ & 340 & 0.36 & 122.4 \\
\hline - chemicals & 1 & 3 & 7.2 & 21.6 \\
\hline - fuel & 1 & 124.12 & 1.2 & 148.9 \\
\hline - engine oil & 1 & & & 6.0 \\
\hline - services of harvest & ha & & & 80.0 \\
\hline - insurance & $€$ & & & 3.8 \\
\hline - interest on the credit for operating capital & $€$ & & & 6.1 \\
\hline - other variable costs & $€$ & & & 4.2 \\
\hline Total costs & & & & 393 \\
\hline
\end{tabular}

Source: Author's calculation

The calculation of certain categories of production value and costs is based on natural indicators that are determined on the basis of the survey conducted on the family farms. The calculation of production value and costs intended to get the realistic picture of the financial results obtained at the concrete family farms. In this way it is ensured that the resulting economic parameters have not only the local, but also the general importance (Popović, 2016). 
In the case of extensive crop production, the average yield of oat grains is $2.1 \mathrm{t} / \mathrm{ha}$, while the yield of oat straw is $1.7 \mathrm{t} / \mathrm{ha}$. The average yield of barley grain is $2.2 \mathrm{t} / \mathrm{ha}$, but the yield of barley straw is $1.8 \mathrm{t} / \mathrm{ha}$. In extensive crop production, it is applied one plowing, and with reduced fertilization of crops, as well as it is obtained lower yield compared to the intensive crop production. In extensive crop production, yield of hay from natural meadow is $2.1 \mathrm{t} /$ ha, while the hay from cultivated meadow is $5.4 \mathrm{t} /$ ha (Tables 2-5).

Table 3. Costs of production per 1 ha of barley - extensive crop production

\begin{tabular}{|c|c|c|c|c|}
\hline Indicators & $\begin{array}{c}\text { Unit of } \\
\text { measure }\end{array}$ & Volume & Price $(€)$ & Sum $(€)$ \\
\hline \multicolumn{5}{|l|}{ 1. Production value } \\
\hline - grain & $\mathrm{kg}$ & 2,200 & \multicolumn{2}{|c|}{ internal realization } \\
\hline - straw & $\mathrm{kg}$ & 1,800 & \multicolumn{2}{|c|}{ internal realization } \\
\hline \multicolumn{5}{|l|}{ 2. Direct variable costs } \\
\hline - fertilizers & $\mathrm{kg}$ & 350 & 0.36 & 126.0 \\
\hline - chemicals & 1 & 3 & 7.2 & 21.6 \\
\hline - fuel & 1 & 124.12 & 1.2 & 148.9 \\
\hline - engine oil & 1 & & & 6.0 \\
\hline - services of harvest & ha & & & 80 \\
\hline - insurance & $€$ & & & 4.2 \\
\hline - interest on the credit for operating capital & $€$ & & & 6.3 \\
\hline - other variable costs & $€$ & & & 4.0 \\
\hline Total costs & & & & 397 \\
\hline
\end{tabular}

Source: Author's calculation

Table 4. Costs of production of 1 ha of hay from the natural meadows - extensive crop production

\begin{tabular}{|c|c|c|c|c|}
\hline Indicators & $\begin{array}{c}\text { Unit of } \\
\text { measure }\end{array}$ & Volume & Price (€) & $\operatorname{Sum}(€)$ \\
\hline \multicolumn{5}{|l|}{ 1. Production value } \\
\hline - straw & $\mathrm{kg}$ & 2,100 & \multicolumn{2}{|c|}{ internal realization } \\
\hline \multicolumn{5}{|l|}{ 2. Direct variable costs } \\
\hline - fertilizers & $\mathrm{kg}$ & 230 & 0.36 & 82.8 \\
\hline - fuel & 1 & 31.32 & 1.2 & 37.6 \\
\hline - engine oil & 1 & & & 1.50 \\
\hline - other variable costs & $€$ & & & 5.1 \\
\hline Total costs & & & & 127 \\
\hline
\end{tabular}

Source: Author's calculation

The selection of crops that can be grown in the mountainous areas is very narrow. Thus, on the arable lands there can be grown only barley and oat. It is assumed that farmers have their own seeds for planting crops - oat and barley. The model is based on the assumption that the norms the oat, barley and grass seed (meadows sown) per 1 ha which do not change and that they are the same for extensive and intensive crop production. 
Norms of mineral fertilizers $(\mathrm{kg} / \mathrm{ha})$ in the extensive crop production are as follows: for oat $340 \mathrm{~kg} / \mathrm{ha}$, for barley $350 \mathrm{~kg} / \mathrm{ha}$, for sown meadows $330 \mathrm{~kg} / \mathrm{ha}$ and for natural meadows $230 \mathrm{~kg} / \mathrm{ha}$. In the intensive crop production norms of mineral fertilizers are as follows: for oat $550 \mathrm{~kg} / \mathrm{ha}$, for barley $590 \mathrm{~kg} / \mathrm{ha}$, for sown meadows $580 \mathrm{~kg} / \mathrm{ha}$ and for natural meadows $430 \mathrm{~kg} / \mathrm{ha}$.

Table 5. Costs of the hay production from the sown meadows per 1 ha - extensive crop production

\begin{tabular}{|c|c|c|c|c|}
\hline Indicators & $\begin{array}{c}\text { Unit of } \\
\text { measure }\end{array}$ & Volume & Price $(€)$ & Sum $(€)$ \\
\hline \multicolumn{5}{|l|}{ 1. Production value } \\
\hline - straw & $\mathrm{kg}$ & 5,400 & \multicolumn{2}{|c|}{ internal realization } \\
\hline \multicolumn{5}{|l|}{ 2. Direct variable costs } \\
\hline - seed & $\mathrm{kg}$ & 36 & 3 & 108.0 \\
\hline - fertilizers & $\mathrm{kg}$ & 330 & 0.36 & 118.8 \\
\hline - chemicals & 1 & 3 & 7.2 & 21.6 \\
\hline - fuel & 1 & 240.12 & 1.2 & 288.1 \\
\hline - engine oil & 1 & & & 11.5 \\
\hline - insurance & $€$ & & & 4.8 \\
\hline - interest on the credit for operating capital & $€$ & & & 7.0 \\
\hline - other variable costs & $€$ & & & 5.2 \\
\hline Total costs & & & & 565 \\
\hline
\end{tabular}

Source: Author's calculation

Table 6. Costs of oat production per 1 ha - intensive crop production

\begin{tabular}{|c|c|c|c|c|}
\hline Indicators & $\begin{array}{c}\text { Unit of } \\
\text { measure }\end{array}$ & Volume & Price $(€)$ & $\operatorname{Sum}(€)$ \\
\hline \multicolumn{5}{|l|}{ 1. Production value } \\
\hline - grain & $\mathrm{kg}$ & 2,800 & \multicolumn{2}{|c|}{ internal realization } \\
\hline - straw & $\mathrm{kg}$ & 2,300 & \multicolumn{2}{|c|}{ internal realization } \\
\hline \multicolumn{5}{|l|}{ 2. Direct variable costs } \\
\hline - fertilizers & $\mathrm{kg}$ & 550 & 0.36 & 198.0 \\
\hline - chemicals & 1 & 4.44 & 7.2 & 32.0 \\
\hline - fuel & 1 & 129.92 & 1.2 & 155.9 \\
\hline - engine oil & 1 & & & 6.2 \\
\hline - services of harvest & ha & & & 80.0 \\
\hline - insurance & $€$ & & & 9.1 \\
\hline - interest on the credit for operating capital & $€$ & & & 15.4 \\
\hline - other variable costs & $€$ & & & 13.4 \\
\hline Total costs & & & & 510 \\
\hline
\end{tabular}

Source: Author's calculation 
In the case of intensive crop production, the average yield of oat grains is $2.8 \mathrm{t} / \mathrm{ha}$, while the yield of oat straw is $2.3 \mathrm{t} / \mathrm{ha}$. The average yield of barley grain is $3.2 \mathrm{t} / \mathrm{ha}$, but the yield of barley straw is $2.4 \mathrm{t} / \mathrm{ha}$. Yield of hay from natural meadow is $3.1 \mathrm{t} / \mathrm{ha}$, while the silage from cultivated meadow is $22.13 \mathrm{t} /$ ha (Table 6-9).

Norms of tractor use (hour/ha) in the extensive crop production are as follows: for oat 21.4 hours/ha, for barley 21.4 hours/ha, for cultivated meadows 41.4 hours/ha and for natural meadows 5.4 hours/ha. In the intensive crop production this norms are: for oat 22.4 hours/ha, for barley 22.0 hours/ha, for cultivated meadows 48.3 hours/ha and for natural meadows 6.5 hours/ha. The assumption is that the fuel consumption per hour is 5.8 liters.

Table 7. Costs of barley production per 1 ha - intensive crop production

\begin{tabular}{|c|c|c|c|c|}
\hline Indicators & $\begin{array}{c}\text { Unit of } \\
\text { measure }\end{array}$ & Volume & Price $(€)$ & $\operatorname{Sum}(€)$ \\
\hline \multicolumn{5}{|l|}{ 1. Production value } \\
\hline - grain & $\mathrm{kg}$ & 3,200 & \multicolumn{2}{|c|}{ internal realization } \\
\hline - straw & $\mathrm{kg}$ & 2,400 & \multicolumn{2}{|c|}{ internal realization } \\
\hline \multicolumn{5}{|l|}{ 2. Direct variable costs } \\
\hline - fertilizers & $\mathrm{kg}$ & 590 & 0.36 & 212.4 \\
\hline - chemicals & 1 & 4.44 & 7.2 & 32.0 \\
\hline - fuel & 1 & 127.6 & 1.2 & 153.1 \\
\hline - engine oil & 1 & & & 6.1 \\
\hline - services of harvest & ha & & & 80 \\
\hline - insurance & $€$ & & & 8.9 \\
\hline - interest on the credit for operating capital & $€$ & & & 14.6 \\
\hline - other variable costs & $€$ & & & 13.9 \\
\hline Total costs & & & & 521 \\
\hline
\end{tabular}

Source: Author's calculation

Table 8. Costs of hay production from natural meadows per 1 ha - intensive crop production

\begin{tabular}{|c|c|c|c|c|}
\hline Indicators & $\begin{array}{c}\text { Unit of } \\
\text { measure }\end{array}$ & Volume & Price $(€)$ & Sum $(€)$ \\
\hline \multicolumn{5}{|l|}{ 1. Production value } \\
\hline - hay & $\mathrm{kg}$ & 3,100 & \multicolumn{2}{|c|}{ internal realization } \\
\hline \multicolumn{5}{|l|}{ 2. Direct variable costs } \\
\hline - fertilizers & $\mathrm{kg}$ & 430 & 0.36 & 154.8 \\
\hline - fuel & 1 & 37.7 & 1.2 & 45.2 \\
\hline - engine oil & 1 & & & 1.8 \\
\hline - other variable costs & $€$ & & & 13.2 \\
\hline Total costs & & & & 215 \\
\hline
\end{tabular}

Source: Author's calculation 
Table 9. Costs of silage production from cultivated meadows per 1 ha - intensive crop production

\begin{tabular}{|c|c|c|c|c|}
\hline Indicators & $\begin{array}{c}\text { Unit of } \\
\text { measure }\end{array}$ & Volume & Price $(€)$ & $\operatorname{Sum}(€)$ \\
\hline \multicolumn{5}{|l|}{ 1. Production value } \\
\hline - silage & $\mathrm{kg}$ & 22,130 & \multicolumn{2}{|c|}{ internal realization } \\
\hline \multicolumn{5}{|l|}{ 2. Direct variable costs } \\
\hline - seed & $\mathrm{kg}$ & 36 & 4 & 144.0 \\
\hline - fertilizers & $\mathrm{kg}$ & 580 & 0.36 & 208.8 \\
\hline - chemicals & 1 & 6.0 & 7.2 & 43.2 \\
\hline- fuel & 1 & 280.14 & 1.2 & 336.2 \\
\hline - engine oil & 1 & & & 13.4 \\
\hline - insurance & $€$ & & & 13.8 \\
\hline - interest on the credit for operating capital & $€$ & & & 16.8 \\
\hline - other variable costs & $€$ & & & 13.8 \\
\hline Total costs & & & & 790 \\
\hline
\end{tabular}

Source: Author's calculation

The needed amount of forage at models of family farms for extensive and intensive crop and sheep production, average yields and necessary arable land are given in table 10 .

Table 10. The required annual mount of forage per farm, average yields and farmland for extensive and intensive crop and sheep production

\begin{tabular}{|c|c|c|c|}
\hline Type of forage & Amount of forage (t) & Yield (t/ha) & Farmland (ha) \\
\hline \multicolumn{4}{|c|}{ Extensive crop production - extensive sheep production (model A) } \\
\hline - oat & 3.27 & 2.1 & 1.56 \\
\hline - barley & 1.57 & 2.2 & 0.71 \\
\hline - natural meadow hay & \multirow{2}{*}{38.09} & 2.1 & 5.08 \\
\hline - cultivated meadow hay & & 5.4 & 5.08 \\
\hline - pasturage & 91.94 & 0.7 & - \\
\hline - concentrate & 3.45 & - & - \\
\hline \multicolumn{4}{|c|}{ Intensive crop production - extensive sheep production (model B) } \\
\hline - oat & 3.27 & 2.8 & 1.17 \\
\hline - barley & 1.57 & 3.2 & 0.49 \\
\hline - natural meadow hay & 7.62 & 3.1 & 2.46 \\
\hline - grass silage & 75.44 & 22.13 & 3.41 \\
\hline - pasturage & 91.94 & 1.2 & - \\
\hline - concentrates & 3.45 & - & - \\
\hline \multicolumn{4}{|c|}{ Extensive crop production - intensive sheep production (model C) } \\
\hline - oat & 3.89 & 2.1 & 1.85 \\
\hline - barley & 1.87 & 2.2 & 0.85 \\
\hline - natural meadow hay & \multirow{2}{*}{50.26} & 2.1 & 6.70 \\
\hline - cultivated meadow hay & & 5.4 & 6.70 \\
\hline - pasturage & 107.59 & 0.7 & - \\
\hline - concentrates & 5.79 & - & - \\
\hline \multicolumn{4}{|c|}{ Intensive crop production - intensive sheep production (model D) } \\
\hline - oat & 3.89 & 2.8 & 1.39 \\
\hline - barley & 1.87 & 3.2 & 0.58 \\
\hline - natural meadow hay & 10.44 & 3.1 & 3.37 \\
\hline - grass silage & 98.56 & 22.13 & 4.48 \\
\hline - pasturage & 107.59 & 1.2 & - \\
\hline - concentrates & 5.79 & - & - \\
\hline
\end{tabular}

Source: According to Krstic et al., 1995. 
Based on the table 10, the total area of arable land for forage production amounts to the following: model A 12.43 ha, model B 7.53 ha, model C 16.10 ha and model D 9.82 ha. From 4 tested models, one model (model C) does not satisfy the assumption that arable land amounts to 15 hectares. In this case, the needed forage quantity will be provide by renting of certain areas.

\section{Sheep production}

Differences between the defined models are mainly related to the fact whether the production is of extensive or intensive type. In extensive sheep production the sheep fertility is lower, the lower is the production of milk and thus the quantity of the cheese is lower. The intensive sheep production implies the higher investment and the economic effects of the sold lambs and cheese will be higher as well. Also it is higher the average annual number of lambs. In addition, there are differences in weight of adult culled sheep and rams, as well as in wool production, depending on the fact is it obtained in extensive or intensive sheep production. Zoo-technical and production indicators of sheep production are given in table 11.

Table 11. Basic zoo-technical and production indicators of sheep production on family farms

\begin{tabular}{|c|c|c|}
\hline \multirow{2}{*}{ Indicators } & \multicolumn{2}{|c|}{ Sheep production } \\
\hline & Extensive & Intensive \\
\hline \multicolumn{3}{|l|}{ 1. Exploitation period of breeding animals (years): } \\
\hline - sheep & 6 & 5 \\
\hline- rams & 5 & 4 \\
\hline 2. Fertility of sheep (\%) & $105-110 \%$ & $120-130 \%$ \\
\hline 3. The number of sheep per breeding ram & 33 & 25 \\
\hline 4. Lambs mortality (\%) & 4 & 5 \\
\hline 5. Restoration (repair) of the flock (\%) & 17 & 20 \\
\hline \multicolumn{3}{|l|}{ 6. Body volume $(\mathrm{kg})$ : } \\
\hline - female lambs at birth & $3.0-3.2$ & $3.6-3.8$ \\
\hline - male lambs at birth & $3.2-3.4$ & $3.8-4.0$ \\
\hline - female lambs when they are selling & 28 & 30 \\
\hline - male lambs when they are selling & 32 & 34 \\
\hline - adult culled sheep & 52 & 60 \\
\hline - adult culled ram & 70 & 85 \\
\hline 7. Annual milk production per breeding ewe $(\mathrm{kg}) *$ & $54-57$ & $60-65$ \\
\hline 8. Annual production of cheese per breeding ewe $(\mathrm{kg})$ & $9.0-9.5$ & $10.0-10.8$ \\
\hline \multicolumn{3}{|l|}{ 9. The annual production of wool $(\mathrm{kg})$} \\
\hline - per sheep & 2.0 & 2.4 \\
\hline - per ram & 2.5 & 3.0 \\
\hline
\end{tabular}

* Not included the quantity of milk that lambs suckle

Source: Author's calculation based on the questionnaire

The model A with 100 sheep and 3 rams gets about 105 lambs per year. If mortality of lambs is $4 \%$ and if some of the lambs are used for household purposes (5 lambs per year), in total will remain 96 lambs (48 female lambs and 48 male lambs). Out of 48 female lambs, 17 is used for renewal of the flock, i.e. they are left to "repair" the flock, as well as 1 male lamb. For sale remain: 47 male lambs, 31 female lambs, 17 sheep and 1 ram. 
In a similar way can be calculated the number of lambs that could be sold in other family farm models. Thus, in B model there could be sold 33 female lambs, 49 male lambs, 17 sheep and $1 \mathrm{ram}$. In $\mathrm{C}$ model there could be sold 37 female lambs, 56 male lambs, 20 sheep and $1 \mathrm{ram}$. In D model there could be sold 39 female lambs, 58 male lambs, 20 sheep and 1 ram.

\section{Calculation of production value, costs and gross margin in the family farm models}

Based on zoo-technical and production indicators of sheep production on family farms, it was calculated the total production value (table 12). In this case the value of production is identified with total revenues (income) that are realized on the family farms.

Table 12. Total value of production (income) on the family farms

\begin{tabular}{|c|c|c|c|c|}
\hline Indicators & Unit & Quantity & Price (€) & Value $(€)$ \\
\hline \multicolumn{5}{|c|}{ Model $A-$ extensive crop and extensive sheep production } \\
\hline \multicolumn{5}{|l|}{ 1. Production value: } \\
\hline - lambs & $\mathrm{kg}$ & 2,372 & 2.3 & $5,455.6$ \\
\hline - culled sheeps and rams & $\mathrm{kg}$ & 954 & 1.8 & $1,717.2$ \\
\hline - milk & 1 & 4,500 & / & $3,375^{*}$ \\
\hline - wool & $\mathrm{kg}$ & 207.5 & 0.65 & 134.9 \\
\hline Total production value - model A & & & & $10,682.7$ \\
\hline \multicolumn{5}{|c|}{ Model B-intensive crop and extensive sheep production } \\
\hline \multicolumn{5}{|l|}{ 1. Production value: } \\
\hline - lambs & $\mathrm{kg}$ & 2,492 & 2.3 & $5,731.6$ \\
\hline - culled sheep and rams & $\mathrm{kg}$ & 954 & 1.8 & $1,717.2$ \\
\hline - milk & 1 & 4,752 & 1 & $3,564^{*}$ \\
\hline - wool & $\mathrm{kg}$ & 207,5 & 0.65 & 134.9 \\
\hline Total production value - model B & & & & $11,147.7$ \\
\hline \multicolumn{5}{|c|}{ Model $C-$ extensive crop and intensive sheep production } \\
\hline \multicolumn{5}{|l|}{ 1. Production value: } \\
\hline - lambs & $\mathrm{kg}$ & 3,014 & 2.3 & $6,932.2$ \\
\hline - culled sheep and rams & $\mathrm{kg}$ & 1,285 & 1.8 & $2,313.0$ \\
\hline - milk & 1 & 4.860 & 1 & $3,645^{*}$ \\
\hline - wool & $\mathrm{kg}$ & 252 & 0.65 & 163.8 \\
\hline Total production value - model $\mathrm{C}$ & & & & 13,054 \\
\hline \multicolumn{5}{|c|}{ Model D-intensive crop and intensive sheep production } \\
\hline \multicolumn{5}{|l|}{ 1. Production value: } \\
\hline - lambs & $\mathrm{kg}$ & 3,142 & 2.3 & $7,226.6$ \\
\hline - culled sheep and rams & $\mathrm{kg}$ & 1,285 & 1.8 & $2,313.0$ \\
\hline - milk & 1 & 5,160 & 1 & $3,870^{*}$ \\
\hline - wool & $\mathrm{kg}$ & 252 & 0.65 & 163.8 \\
\hline Total production value - model D & & & & $13,573.4$ \\
\hline
\end{tabular}

* Value of the cheese produced from the quantity of milk.

Source: Author's calculation based on the questionnaire 
In tables $13,14,15$ and 16 there are calculated the total variable costs which are realized on family farms when crop and sheep production are within extensive or intensive type. It can be seen from the tables that the most amount of costs belongs to the costs of sheep feed. The largest share in the structure of variable costs have hay from the cultivated meadows $(42.14 \%-43.08 \%)$, then the grass silage $(41.32 \%-41.96 \%)$ and finally form the concentrates $(13.17 \%-17.85 \%)$.

Table 13. Total variable costs on the family farm - model A

\begin{tabular}{|c|c|c|c|}
\hline Variable costs & Description & Value (€) & Structure (\%) \\
\hline - oat & $1.56 \mathrm{ha} \cdot 393 € / \mathrm{ha}$ & 613.1 & 9.00 \\
\hline - barley & 0.71 ha $\cdot 397 € /$ ha & 281.9 & 4.14 \\
\hline - hay from natural meadows & $5.08 \mathrm{ha} \cdot 127 € / \mathrm{ha}$ & 645.2 & 9.47 \\
\hline - hay from cultivated meadows & $5.08 \mathrm{ha} \cdot 565 € / \mathrm{ha}$ & $2,870.2$ & 42.14 \\
\hline - concentrates & $3.45 \mathrm{t} \cdot 260 € / \mathrm{t}$ & 897.0 & 13.17 \\
\hline Variable costs & Description & Value $(€)$ & Structure (\%) \\
\hline - animal salt & $0.36 \mathrm{t} \cdot 500 € / \mathrm{t}$ & 180.0 & 2.64 \\
\hline - mineral-vitamin supplements & $0.12 \mathrm{t} \cdot 1,200 € / \mathrm{t}$ & 144.0 & 2.11 \\
\hline \multicolumn{2}{|l|}{ - health care for livestock } & 200.0 & 2.94 \\
\hline \multicolumn{2}{|l|}{ - use of public pastures } & 130.0 & 1.91 \\
\hline \multicolumn{2}{|l|}{ - insurance of livestock } & 224.0 & 3.29 \\
\hline \multicolumn{2}{|c|}{ - interest on the credit for operating capital } & 102.0 & 1.50 \\
\hline \multicolumn{2}{|c|}{ - other costs } & 523.0 & 7.68 \\
\hline \multicolumn{2}{|l|}{ Total variable costs } & $6,810.4$ & 100 \\
\hline
\end{tabular}

Source: Author's calculation

Table 14. Total variable costs on the family farm - model B

\begin{tabular}{|l|l|r|c|}
\hline \multicolumn{1}{|c|}{ Variable costs } & \multicolumn{1}{c|}{ Description } & \multicolumn{1}{c|}{ Value (€) } & \multicolumn{1}{c|}{ Structure (\%) } \\
\hline - oat & $1.17 \mathrm{ha} \cdot 510 € / \mathrm{ha}$ & 596.7 & 9.15 \\
\hline - barley & $0.49 \mathrm{ha} \cdot 521 € / \mathrm{ha}$ & 255.3 & 3.91 \\
\hline - hay from natural meadows & $2.46 \mathrm{ha} \cdot 215 € / \mathrm{ha}$ & 528.9 & 8.11 \\
\hline - grass silage & $3.41 \mathrm{ha} \cdot 790 € / \mathrm{ha}$ & $2,693.9$ & 41.32 \\
\hline - concentrates & $3.45 \mathrm{t} \cdot 260 € / \mathrm{t}$ & 897.0 & 13.76 \\
\hline - animal salt & $0.36 \mathrm{t} \cdot 500 € / \mathrm{t}$ & 180.0 & 2.76 \\
\hline - mineral-vitamin supplements & $0.12 \mathrm{t} \cdot 1,200 € / \mathrm{t}$ & 144.0 & 2.21 \\
\hline - health care for livestock & 210.0 & 3.22 \\
\hline - use of the public pastures & 130.0 & 1.99 \\
\hline - insurance of livestock & 224.0 & 3.43 \\
\hline - interest on the credit for operating capital & 108.0 & 1.66 \\
\hline - other costs & 552.0 & 8.47 \\
\hline Total variable costs & $\mathbf{6 , 5 1 9 . 8}$ & $\mathbf{1 0 0}$ \\
\hline
\end{tabular}

Source: Author's calculation 
Table 15. Total variable costs on the family farm - model C

\begin{tabular}{|l|l|r|c|}
\hline \multicolumn{1}{|c|}{ Variable costs } & \multicolumn{1}{c|}{ Description } & \multicolumn{1}{c|}{ Value (€) } & \multicolumn{1}{c|}{ Structure (\%) } \\
\hline - oat & $1.85 \mathrm{ha} \cdot 393 € / \mathrm{ha}$ & 727,1 & 8.27 \\
\hline - barley & $0.85 \mathrm{ha} \cdot 397 € / \mathrm{ha}$ & 337,4 & 3.84 \\
\hline - hay from natural meadows & $6.70 \mathrm{ha} \cdot 127 € / \mathrm{ha}$ & 850.9 & 9.68 \\
\hline - hay from cultivated meadows & $6.70 \mathrm{ha} \cdot 565 € / \mathrm{ha}$ & $3,785.5$ & 43.08 \\
\hline - concentrates & $5.79 \mathrm{t} \cdot 260 € / \mathrm{t}$ & $1,505.4$ & 17.13 \\
\hline - animal salt & $0.36 \mathrm{t} \cdot 500 € / \mathrm{t}$ & 180.0 & 2.05 \\
\hline - mineral-vitamin supplements & $0.12 \mathrm{t} \cdot 1,200 € / \mathrm{t}$ & 144.0 & 1.64 \\
\hline - health care for livestock & 220.0 & 2.50 \\
\hline - use of the public pastures & 130.0 & 1.48 \\
\hline - insurance of livestock & 224.0 & 2.55 \\
\hline - interest on the credit for operating capital & 110.0 & 1.25 \\
\hline - other costs & 573.0 & 6.52 \\
\hline Total variable costs & $\mathbf{8 , 7 8 7 . 3}$ & $\mathbf{1 0 0}$ \\
\hline
\end{tabular}

Source: Author's calculation

Table 16. Total variable costs on the family farm - model D

\begin{tabular}{|l|l|r|c|}
\hline \multicolumn{1}{|c|}{ Variable costs } & \multicolumn{1}{c|}{ Description } & \multicolumn{1}{c|}{ Value (€) } & \multicolumn{1}{c|}{ Structure (\%) } \\
\hline - oat & $1.39 \mathrm{ha} \cdot 510 € / \mathrm{ha}$ & 708.9 & 8.40 \\
\hline - barley & $0.58 \mathrm{ha} \cdot 521 € / \mathrm{ha}$ & 302.2 & 3.58 \\
\hline - hay from natural meadows & $3.37 \mathrm{ha} \cdot 215 € / \mathrm{ha}$ & 724.6 & 8.59 \\
\hline - grass silage & $4.48 \mathrm{ha} \cdot 790 € / \mathrm{ha}$ & $3,539.2$ & 41.96 \\
\hline - concentrates & $5.79 \mathrm{t} \cdot 260 € / \mathrm{t}$ & $1,505.4$ & 17.85 \\
\hline \multicolumn{1}{|c|}{ Variable costs } & Description & Value $(\boldsymbol{\epsilon})$ & \multicolumn{1}{c|}{ Structure (\%) } \\
\hline - animal salt & $0.36 \mathrm{t} \cdot 500 € / \mathrm{t}$ & 180.0 & 2.13 \\
\hline - mineral-vitamin supplements & $0.12 \mathrm{t} \cdot 1,200 € / \mathrm{t}$ & 144.0 & 1.71 \\
\hline - health care for livestock & 230.0 & 2.73 \\
\hline - use of the public pastures & 130.0 & 1.54 \\
\hline - insurance of livestock & 224.0 & 2.66 \\
\hline - interest on the credit for operating capital & 133.0 & 1.58 \\
\hline - other costs & 614.0 & 7.28 \\
\hline Total variable costs & $\mathbf{8 , 4 3 5 . 3}$ & $\mathbf{1 0 0}$ \\
\hline
\end{tabular}

\section{Source: Author's calculation}

On the second place in the structure of variable costs, there are costs of oat, barley and hay production from natural meadows. Other costs include the costs of the milk processing into the sheep's cheese, electricity and disinfectants costs.

From the calculated production value and costs, it can be calculated the gross margin realize on the family farms: $10,682.7-6,810.4=3,872.3 € /$ year. In other words, the gross margin per sheep amounts to $38.72 €$.

Analytical calculation based on variable costs (Direct costing method) is particularly suitable for calculation of the production costs and results at the family farms. By the direct costing method there could be determined the value of production, variable 
costs and gross margin. The gross margin represents an intermediate result or financial indicator in which consists from a part which covers the fixed costs and the part which represent the profit. In other words, the gross margin shows the amount after covering the variable costs that rests for covering the fixed costs and achieved positive financial result. The gross margin is calculated when the variable costs are deducted from the value of production. In this way it was calculated the gross margin which has been realized in different family farm models (table 17).

Table 17. Total value of production, variable costs and gross margin at analyzed models

\begin{tabular}{|l|c|c|c|}
\hline \multicolumn{1}{|c|}{ Models } & $\begin{array}{c}\text { Value of production } \\
(\boldsymbol{\epsilon})\end{array}$ & Variable costs $(\boldsymbol{\epsilon})$ & Gross margin $(\boldsymbol{\epsilon})$ \\
\hline Model A & $10,682.7$ & $6,810.4$ & $3,872.3$ \\
\hline Model B & $11,147.7$ & $6,519.8$ & $4,627.9$ \\
\hline Model C & $13,054.0$ & $8,787.3$ & $4,266.7$ \\
\hline Model D & $13,573.4$ & $8,435.3$ & $5,138.1$ \\
\hline
\end{tabular}

Source: Author's calculation

The gross margin coverage is the highest in the model $\mathrm{D}$ with intensive crop production and intensive sheep production and it amounts to 5,138.1 €. In contrast, in model A, with the extensive type of crop and sheep production it has been achieved the minimal value of production and relatively high variable costs, resulting in the gross margin of 3,872.3 $€$. Under the conditions of extensive sheep production, the best economic indicators have been achieved in the model B. In intensive sheep production the best economic results have been achieved in the model D. Also, the model B has a lower value of production and lower variable costs $(6.519 .8 €)$ in comparison with the model $\mathrm{C}$, but still achieves the higher gross margin, because at model $\mathrm{C}$ the variable costs are the highest $(8,787.3 €)$.

\section{Conclusion}

The Republic of Serbia is a country where agriculture occupies an important place in the overall economic structure. Favorable natural and climatic conditions and rich land resources enable the organization and implementation of economically justified agricultural production. Sheep production is of increasing importance for the overall agricultural production.

The hilly-mountainous regions of Serbia represent a significant potential for the economic development of the country. The sheep production which can be organized in those regions has comparative advantages in relation to some other productions that could not be successfully organized in those regions. They are particularly convenient for the hilly-mountain family farms.

In order to examine the profitability sheep production on the hilly-mountain family farms in different level of intensity concerning the crop production and sheep production, there have been constructed 4 models of sheep production which differ in intensity of crop 
and sheep production (A model extensive crop production - extensive sheep production, B model - intensive crop production - extensive sheep production, $\mathrm{C}$ model extensive crop production - intensive sheep production and Model D - intensive crop production - intensive sheep production). The economic indicators of production have shown that adequate care and nutrition of sheep contribute to the achievement of the successful economic results. The best economic results have been achieved in the Model D.

A common feature of all models is that on the basis of obtained results it can be concluded these models are reliable and can be applied in real business conditions, particularly in the case of the hilly-mountain family farms.

\section{Conflict of interests}

The author declare no conflict of interest.

\section{References}

1. Andrić J. (1998). Costs and calculations in agricultural production, Modern administration, Belgrade. [in Serbian: Андрић J. (1998). Трошкови и калкулације у пољопривредној производњи].

2. Bulatović B. (1996). Choice of the livestock production system on family farms located in Northern Montenegro, Doctoral dissertation, University of Belgrade, Faculty of Agriculture, Belgrade. [in Serbian: Избор система сточарске производње на породичним газдинствима сјеверног дијела Црне Горе].

3. Gogić P. (2009). Theory of the costs with calculations in the production and processing of agricultural products, University of Belgrade, Faculty of Agriculture, Belgrade. [in Serbian: Теорија трошкова са калкулацијама у производњи и преради пољопривредних производа].

4. Jovanović S., Maćej O., Barać M. (2004). Characteristics of native cheese production in the area of Sjenica-Pester plateau, Biotechnology in Animal Husbandry, 20 (1-2), 131-139. doi:10.2298/BAH0402131J [in Serbian: Карактеристике аутохтоне производње сјеничког сира на подручју Сјеничко-пештерске висоравни].

5. Krajinović M. (2006). Sheep breeding and goat breeding, University of Novi Sad, Faculty of agriculture, Novi Sad. [in Serbian: Овчарство и козарство].

6. Krstić B., Andrić J., Bajčetić B. (1995). Models of family farms focused on livestock production, Aleksandrija, Belgrade. [in Serbian: Модели земљорадничких газдинстава усмерених на сточарску производњу].

7. Mekić C., Lalović M., Pandurević T. (2006). An reproduction indicator race of sheep Ile de France on the farm Ponikve, Agro-knowledge journal, 7 (2), 37-44. [in Serbian: Репродуктивни показатељи оваца расе Ile de France на фарми Поникве].

8. Pavličević A. (2001). Nutrition of cattle and sheep, University of Belgrade, Faculty of Agriculture, Belgrade. [in Serbian: Исхрана говеда и оваца]. 
9. Pavličević A., Stojković M., Grubić G. (2000). Important factors that affect the performance of fattening lambs, XV consulting agronomists, veterinarians and technologists - Thematic Proceedings of scientific papers, Arandjelovac, 6 (2), 481-488. [in Serbian: Важнији фактори који утичу на производне резултате у тову јагњади].

10. Pethick DW., Warner RD., Banks RG, (2006). Genetic improvement of lamb industry issues and the need for integrated research, Australian journal of agricultural research, CSIRO Publishing, 57 (6), 591-592, doi: 10.1071/ Arv57n6_PR.

11. Popović N. (2012). Economic profitability of buckwheat production on family farms, Master thesis, University of Belgrade, Faculty of Agriculture, Belgrade. [in Serbian: Економска исплативост производње хељде на породичним газдинствима].

12. Popović N. (2016). Economic aspects of sheep production on a family farm at Pester plateau, Agroekonomika journal, 45 (72), 29-40. [in Serbian: Економски аспекти овчарске производње на породичном газдинству Пештерске висоравни].

13. Sredojević Z., Popović N. (2014). Sheep farming-pastures sustainability: an economic model of sheep farm for rural areas in Serbia, Thematic proceedings, International scientific conference: Sustainable agriculture and rural development in terms of the Republic of Serbia strategic goals realization within Danube region - rural development and (un)limited resources, Institute of agricultural economics, Belgrade, 1006-1023.

14. Tomić R. (1994). Family farms models focused on sheep production in the mountain areas of Serbia, Doctoral dissertation, University of Belgrade, Faculty of agriculture, Belgrade. [in Serbian: Модели породичних газдинстава усмерених на овчарску производњу у планинском подручју Србије].

15. Vasiljević Z., Subić J. (2010). Cost management in agribusiness at Serbia-factor of increase competitiveness, Thematic proceedings, Agroindustry of Serbia and European Integration - (un)suitability implementation of the Trade Agreement, Belgrade, 77-93 [in Serbian: Управљање трошковима у агропривреди Србије-чинилац повећања конкурентности]. 